\title{
The Development of Learning Materials Based on Guided Discovery to Improve the Student's Ability in Mathematical Problem Solving on Second Semester at Grade VIII of Junior High School
}

Nurkumala Sarí, Ahmad Fauan, and Hendra Syarifuddin

Universitas Negeri Padang, Indonesia

\section{Abstract}

Problem solving ability of students do not develope optimaly. One of them is the unavailability of learning materials which facilitates students to increase students mathematical problem solving ability optimally. The purpose of this research is to produce learning instruments based on guided discovery that valid, practice, and

Corresponding Author:

Nurkumala Sari

nurkumalasari21@gmail.com

Received: 18 January 2019

Accepted: 24 March 2019

Published: 31 March 2019

Publishing services provided by

Knowledge E

(c) Nurkumala Sari et al. This article is distributed under the terms of the Creative Commons

Attribution License, which

permits unrestricted use and redistribution provided that the original author and source are credited.

Selection and Peer-review unde the responsibility of the ICEST 2018 Conference Committee.

\section{G OPEN ACCESS} effective to increase students mathematical problem solving ability on second semester at grade VIII of junior high school. Learning instruments that developed were lesson plan (RPP) and student worksheet (LKPD). This research is a development research with Plomp model that consists of three phases, namely preliminary research, development or prototyping phase, and assessment phase. Subjects were students of grade VIII of MTsS PGAI Padang. Data in this research were obtained from validation sheets for RPP, validation sheets for LKPD, sheets of observation for learning process, questionnaire for teacher, questionnaire for students, and final test. Data were analysed by descriptively. Based on the results, learning materials based on guided discovery can be concluded that the learning materials based on guided discovery to improve the student's ability in mathematical problem solving on second semester at grade VIII of junior high school was valid, practice, and effective.

Keywords: Learning Material Based On Guided Discovery, Problem Solving Ability

\section{Introduction}

Mathematics is an important subject to improve skills and intellectual skills. Mathematics is also underlie the modern technology development, has an important role in various disciplines, and advances the human mind. Therefore, mathematics need to be given to the students start from elementary school to higher levels. This is done in order to equip students with some skills that are indispensable in daily life. 
The purposes of mathematics learning are: (1) understanding the mathematical concept, explaining the linkages between concept and apply the concepts or algorithms on a flexible, accurate, efficient and precise in solving the problem, (2) using the reasoning in the patterns and character, doing mathematical manipulation in making generalizations, compiling the evidence or explain mathematical ideas and statements, (3) solving problems which cover the problem-understanding ability, designing mathematical models, solving models and interpreting obtained solutions, (4) communicating ideas by symbols, tables, diagrams or other media to clarify the situation or problems, and (5) having an appreciation of mathematics purposes which are curiosity, attention and interest in learning mathematics, resilience and confidence in solving problems [1]. Based on those purposes, it can be concluded that problem-solving ability is one of important things that must be had by students in mathematics learning. Mathematical problem-solving ability is very important for the students because it has a positive impact in their future to solve various daily life problems.

In the same, there are five mathematical abilities that students should have: (1) learning to communicate (mathematical communication), (2) learning to reason (mathematical reasoning), (3) learning to solve problems (mathematical problem solving), () learning to associate ideas (mathematical connection), and (5) learning to represent ideas (mathematical representation) [2]. This shows that mathematics when studied seriously will form a creative person, critical, scientific thinking, honest, disciplined, thrifty, and tenacious. However, the result of students mathematics learning in Indonesia is not in accordance with the expected purposes. The TIMMS and PISA survey results show that Indonesian students mathematical ability, especially the students mathematical problem solving ability is still low.

Mathematics learning nowadays is procedural. The students do not get use to solve the nonroutine, so that their higher level thinking ability are not trained. Whereas this ability is needed to develop, understand the concept and solve mathematical problems.

The low of students mathematical problem-solving ability was also seen in some schools, for example in SMPN 17 Padang, SMPN 4 Palembayan, and MTsS PGAI Padang. Researchers gave problem-solving skills questions to VIII grade students.

A bus company sets a tariff requirement that the initial tariff (for the first kilometer) is Rp. 100,000 and the rate per next kilometer is Rp. 25,000.

1. What is the $55 \mathrm{~km}$ trip rate?

2. Make a mathematical model of the tariff to be paid by a passenger if he boarded the bus! 
Most of the students answer:

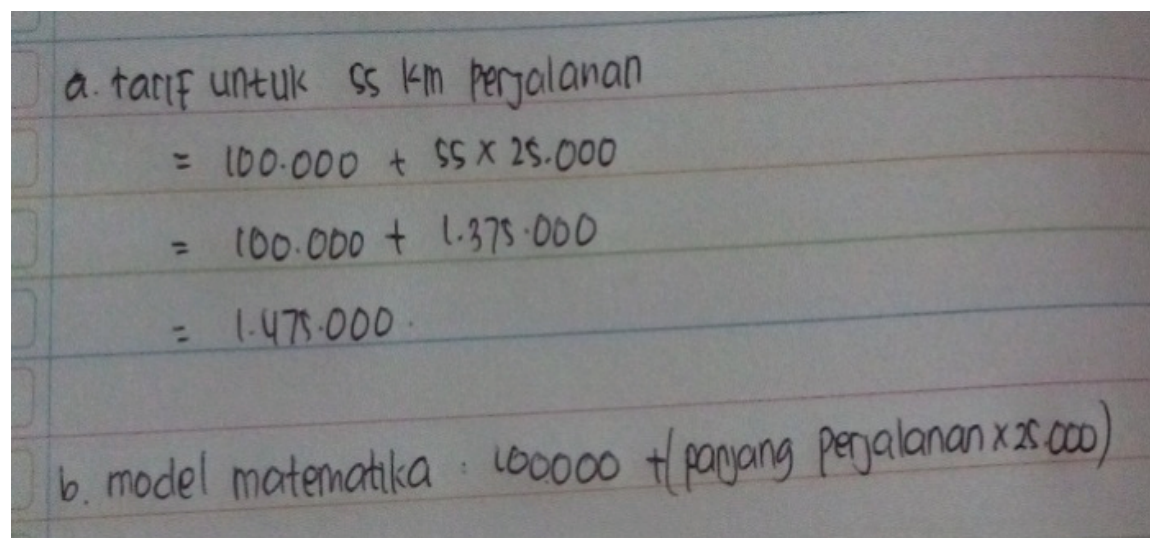

The picture above shows that the students answer on the first question part was correct. To solve the problem at the second part, the answers written by the students were not correct. In solving the second part problem, the students did not understand the problem so the planning of the answer made did not lead to the correct answer, incomplete procedures or solutions and incorrect results. In addition, students were not able to make conclusions of problem-solving process / procedure properly.

The description of students' difficulties in answering the questions of problem-solving ability above was also supported by teachers interviews results in SMPN 17 Padang, SMPN 4 Palembayan, and MTsS PGAI Padang. when students were given a problemsolving question, they could not answer it. They looked confused toward the problemsolving questions. It was caused by the tendency of students to memorize the formulas given in answering the problem-solving questions and they were less able to use the concept if they encounter to a real-life problems related to the concept they had. Furthermore, even students were less able to understand, formulate and implement some strategies to solve such mathematical problems.

The problem about mathematical problems-solving ability needs to find a solution so that no more students who have the low ability to solve such mathematical problems. The way that can be done is to carry out some improvements in the learning process. One of the determinants for learning to be implemented optimally is the use of learning instruments in the classroom.

Learning instruments found in the field had not helped teachers in facilitating students to support the process of achieving mathematics learning purposes. The function of learning instruments is to guide the learning process which consists of syllabus, learning implementation plan (RPP), teaching materials, and learning test results. The RPP used had not used a learning model to involve students actively. 
Other facts were found were the sources of learning was still limited to the compulsary books and Student Working Sheets (LKS) or Student Activity Sheets (LKPD) provided by the school. The technique of presenting the material in the compulsary book and LKPD had not involved students actively in doing discoveries in order to build concepts on the material they learned and improve the problem-solving ability.

LKPD is one of print materials which can facilitate students to interact with the material given. Through LKPD students can also be guided to rediscover a concept. LKPD can facilitate teachers in implementing the learning process. On the other, LKPD also can help students to be active in learning process because it contains tasks and steps that lead students to manage the mindset directly. The teacher's role as a facilitator can be maximized.

Along with the necessary of learning instruments which can support problem-solving skills, it is also necessary a method of learning which can be used as a foundation in developing learning instruments. Learning instruments will be more optimal if it is based on one of the learning methods which have a purpose to improve the students problemsolving ability and teaches how to solve a problem. One method that can be used to achieve this purpose is through guided discovery methods.

Learning by invention model is one way to convey ideas with finding process. In this process students try to find a concept or formula with the guidance of teachers by themselves. Because they find the concepts by themselves, formulas and something like that will understand easily for sure, and they can remember longer, will not forget / erroneously in determining the formula which will be used in solving the problem.

The discovery method is a learning on the learner centered method, so that in its implementation will certainly require more time than expository methods. The students ability will greatly affect the length of time required. In order to reduce this problem it is suggested that discovery method can be presented through a little expository and done in the form of group work [3]. Besides, the process of the invention is also accompanied by teachers' instructions or guidance, which called as guided discovery model then.

Based on this background it will be conducted a research with the title "The Development of Learning Instrument on Guided Discovery-based Learning to Improve Students Mathematical Problem-solving Ability in Semester 2 Grade VIII SMP/MTs"

Based on the problems background above, it can be formulated that problems in this study is "How the characteristics of learning instrument on guided discovery-based learning improve a valid, practical, and effective of students mathematical problemsolving ability in semester 2 grade VIII SMP/ MTs?". 
Based on the problem formulation presented above, the purposes to be achieved in this research is to conduct a valid, practical, and effective guided discovery-based learning instrument to improve students mathematical problem-solving ability in semester 2 grade VIII SMP/MTs.

\section{Ease of Use}

The type of this research is Design Research (DR) using the Plomp model, which consists of three phases, they are preliminary research, prototyping phase, and assessment phase [3]. Preliminary research consists of needs analysis, curriculum analysis, conceptual analysis and students analysis. At the prototyping phase, making this prototype conducted by formative evaluation. The prototyping phase consists of designing learning instruments, self-evaluation, expert review, one-to-one evaluation, small group evaluation. At the assessment phase, field tests were conducted on Grade VIII MTs PGAI Padang to see the practicality and effectiveness. The data research was collected through self evaluation sheets, validation sheets, observation sheets and interview guides, teacher and student response questionnaires, RPP implementation observation sheets, and the final test of mathematical problem-solving ability. The instruments validation were done by three Mathematics lecturers, one Indonesian lecturer, and one Educational Technology lecturer.

\subsection{Learning instrument validity}

\subsubsection{Preliminary research results}

The prototype of Mathematics learning instrument is designed based on preliminary research. There are four main steps in this phase, they are: a) needs analysis, information gathering is conducted on the problems contained in mathematics learning in schools. Information gathering was conducted through observation and interview with SMP/MTs teacher grade VIII; b) the analysis of students, to determine the characteristics of students grade VIII SMP/MTs; c) curriculum analysis, conducted a study of curriculum KTSP for mathematics on grade VIII SMP semseter 2; and d) conceptual analysis, to determine the materials needed in the learning instrument development to achieve the competency achievement indicators.Data and information obtained from the preliminary research phase are taken to be a consideration in preparing learning instruments, RPP 
and LKPD on guided discovery-based learning. Preliminary research phase is the basis for the development or manufacture of prototypes.

\section{a. Characteristics of a lesson plan (RPP) on guided discovery-based learning}

The lesson plan (RPP) serves as a guide for teachers in delivering teaching materials. The RPP is systematically designed which contains of RPP writing components [14]. RPP result draft which was made in the second semester mathematics material of grade VIII SMP/MTs were circles, tangents of circles, cubes and beams, and prisms and limas with time allocations were $2 \times 40$ minutes and $3 \times 40$ minutes. RPP was prepared for each $\mathrm{KD}$ which can be implemented in one or more meetings.

The learning activities presented in RPP refer to guided discovery-based learning integrated in LKPD on guided based discovery. RPP's identity presentation, competency standards, basic competencies, indicators, learning purposes, teaching materials, learning methods, time allocation, learning resources and assessment are similar to RPP in general.Preliminary activities are the first activities in a teaching learning process aimed to attract students motivation and attention to participate actively in the teaching learning process. The core activity is a learning process to achieve the learning purposes. There are guided discovery activities in this core activity, they are:

\subsubsection{The problem formulation with sufficient data}

At the beginning of guided discovery activities, students were given problems which make them have a desire to conduct an investigation. At this phase, the teacher asked students to read the problems which exist in LKPD. After students identified the formulation of the given problem, it was continued with the activities of composing, processing, analyzing data, and arranging conjecture.

\subsubsection{Compiling, processing, analyzing data and arranging conjecture}

After the students read and understood the problem formulation, then they were instructed to follow the next activity. In this activity, students were guided by the teacher in composing, processing, analyzing data, and arranging conjecture. This activity could be seen from the students activities in answering the questions that in LKPD. During 
these activities took place, teachers guided students to show their own ideas. Teachers will help students who are confused in understanding each question.

\subsubsection{Checking the conjecture}

The finding conjectures examined by teachers and students through presentations in front of the class. The teacher checked the conjecture the students made. Other students were also expected to give their opinion. If the one student did not want to express their opinions, then the teacher would ask the other students.

\subsubsection{Setting the correct conjecture}

After students presented the results of the discussion, the teacher would provide reinforcement of the findings. The teacher set the correct conjecture so that students were not confused by the answers they got. In addition, teachers also emphasized the concepts which were discussed and corrected them if there was an inappropriate information from the student presentation.

\subsubsection{The exercises to examine the findings are correct}

The teacher asked the student to do the exercises on LKPD. The purpose of this work was to examine the truth of the result findings. The exercises which were given is in form of problem-solving skills math questions. Teachers monitored and guide students if they were having difficulty during doing the exercises. In addition to examine the findings, the provision of exercise also aimed to see the understanding of students. Teaching learning activity ended with concluding which could be done in the form of making a summary or conclusion about the material that had been learned, asking students to repeat the lesson at home, and the teacher informed the material to be learned at the next meeting.

\section{b. Characteristics of student work sheet (LKPD) on guided based dis- covery}

Characteristics of LKPD are divided into four aspects, namely didactic aspects, content aspects, display aspects, and language aspects. 


\subsubsection{The didactic aspect}

Learning begins by giving problems in daily life related to the material being studied with the aim of arousing students to conduct discovery activities. Students were asked to construct their understanding by resolving the problems given based on their knowledge and questions which must be answered, so they could find their own concepts after getting the conclusions

\subsubsection{Content aspects}

Materials and activities of the invention are presented in accordance with indicators of competency achievement. For example, to reach the indicator "Mention the elements of cube and beam: rib, field/side, diagonal plane, diagonal space, diagonal plane "students was presented about daily life problems in order to make them able to find the concept learned. Problems were adjusted to the level of understanding at grade VIII of SMP/MTs and exercises given were in accordance with the students cognition.

\subsubsection{Language aspects}

LKPD uses standard language in accordance with the enhanced spelling (EYD). LKPD uses simple language, communicative and in accordance with the students level of understanding at grade VIII SMP, so that the material presentation on LKPD can be understood well. Questions in LKPD prepared with a clear sentence to lead students get the expected answers.

\subsubsection{Presentation aspect}

Cover page contained the identity or title of LKPD guided based discovery, the identity column of students as the owner of LKPD, and accompanied by objects pictures in daily life related to the material to be studied. The purpose of images presented is to make them feel familiar toward the material because it is occur in daily life. In addition, there were also some informations for grade VIII of SMP semester 2 on curriculum KTSP, subjects, and identity compilers in LKPD.

\subsubsection{Validity result}




\section{a. Self-evaluation results}

After the design of learning instruments was completed and before consulting and discussing to the experts, self-evaluation occured first to the learning instrument that had been designed. There were three aspects that are evaluated in the RPP, they were accuracy of typing, the use of appropriate words and terms and the use of proper punctuation. There were six aspects that are evaluated in LKPD, namely; the accuracy of typing, the use of appropriate words and terms, proper use of punctuation, appropriate text size, the placement of appropriate image and the availability of places for problem solving. Errors occured in the use of proper punctuation and precision of typing generally. Errors appears often on the RPP and LKPD is the there is no punctuation at the end of the sentence.

\section{b. Experimental instrument validation results (Expert review)}

Mathematics learning instrument on guided based discovery were validated by 5 experts, they were 3 mathematics lecturers, 1 educational technology lecturer and 1 Indonesian language lecturer. Based on the analysis results, the aspects assessed in the guided based discovery RPP were the average of the validity index 0.82 , it can be concluded that LKPD is produced based on a valid guided based discovery with characteristics such as the resulting RPP.

While in LKPD, didactic aspect declared as valid with average of validity index is 0,74 , aspect of content is valid with the average of validity index is 0,78 , aspect of language is valid with average of validity index is 0,75 , and aspect of presenter is valid with an average of the prevalence index is 1.00. Based on the result of LKPD validity analysis as a whole, it can be concluded that LKPD is produced based on valid guided discovery with characteristics such as LKPD produced.

\subsection{Learning devices practicality}

Practicality test aims to find out the benefits, easiness, and the time efficiency usage of guided discovery based learning by teachers and students. Learning instruments that had been valid tested to grade VIII students at MTsS PGAI Padang. 


\subsubsection{One-to-one evaluation results}

Individual evaluation was conducted by requesting three students to use LKPD that had been declared as valid by the expert. They were the students from grade VIII MTsS PGAI Padang which was consist of one student with moderate ability and two others with lowability. Students were asked to pay attention to the presentation, easiness of use, and legibility. Based on the details of the individual evaluations implementation, the revision was limited to sentences only generally.

\subsubsection{Small group evaluation results}

In this evaluation, it was conducted a test to nine students at grade VIII of MTsS PGAI Padang who had different abilities. Students were asked to pay attention to the presentation, easiness of use, time usage, and legibility. Students were given a valid and practical LKPD based on the One-to-One Evaluation phase. Observation results showed that students need high accuracy in using LKPD.

\subsubsection{Large group evaluation results (Field test)}

Tests was conducted in grade VIII.2 MTsS PGAI Padang. This trial was conducted to see the practicality of guided based discovery LKPD that had been validated and revised based on individual evaluation and small group evaluation. The practicality test of this LKPD aimed to know the extent of benefits, convenience use, and efficiency of LKPD time usage by teachers and students. Evaluation of large groups was conducted five times. Practical data of guided discovery-based learning instruments were obtained from teachers' response questionnaire, students' response questionnaire and learning implementation observation.

Practicality questionnaire were given to teachers after all LKPDs were completed in the learning process. Based on the analysis, teachers' response questionnaire toward the practicality was $86,25 \%$, so that learning instruments practicality on guided based discovery is announced very practical. LKPD used is easy to use, interesting, well understood and able to motivate students to learn.

Practicality questionnaire was also given to the students after following all learning using LKPD on guided based discovery. Based on the analysis, LKPD on guided based discovery according to students' response is $84.78 \%$. Thus, it can be concluded that guided based discovery LKPD is very practical according to students' response. The 
developed LKPD is easy to use, interesting, easy to understand and the timing of LKPD work is sufficient.

Observation of learning implementation is focused to see whether the learning has been corresponding with the learning steps that have been designed in the lesson plan and to identify the constraints experienced during the learning process. The result of the analysis on the observation sheet is used as one of the considerations in determining the value of learning instruments practicality. The subjects of mathematics at the school are piloting the guided discovery-based learning instruments. Observation was done 5 times according to the number of RPP designed as many as 5 meetings. Trial implementation of learning with guided discovery based learning instruments conducted in class VIII.2 MTsS PGAI Padang by a mathematics teacher who tought in the class.

Obeservation results showed that learning by using guided discovery-based instruments is better at each meeting. Learning process using guided discovery-based instruments can stimulate students to discover, construct their own knowledge and familiarize students with problem-solving abilities. Based on the analysis results, it was seen that the implementation of learning average level of activities practicality on RPP guided based discovery was $85.24 \%$. Thus, it can be concluded that guided discovery-based learning instruments are very practical based on learning activities implementation.

\subsection{Effectiveness of learning devices}

The effectiveness of mathematics learning instrument is seen from the result of mathematical problem solving test of students by using mathematics guided discovery based learning instrument. The test results will be analyzed by using scoring rubric of mathematics problem solving ability. Learning outcomes obtained by students are compared to the Minimum Standart Criteria (KKM) established by the school. The development of this guided discovery-based learning tool is said to be effective if more than $85 \%$ of students get the score $\geq \mathrm{KKM}$.

The final test results showed that of 21 students who took the test, 18 students or 85.71\% passed it, means the value of students over from the determined KKM score and 3 students or $14.28 \%$ had not completed/passed, means that the value of participants was still under KKM. The completeness of classical learning is declared successful if the percentage of students who complete/pass the study or students who get the score $\geq 75$ and greater or equal to $85 \%$ of the total students. Thus it can be concluded that the use of guided discovery-based learning instruments can improve student learning results on 
problem-solving skills. So mathematics learning instruments on guided discovery-based learning are already effective.

\section{Conclusion}

This research is a development which produces a valid, practical, and effective guided discovery based learning instruments to improve mathematical problem solving ability of students at second semester of grade VIII SMP/ MTs. Based on this conclusion, the researcher suggested to be able to develop the mathematics learning instrument for other materials which is suitable with guided discovery characteristics and can be used as a guidance for the teachers in conducting the teaching learning process.

\section{Acknowledgement}

The author would like to thank to Prof. Dr. Ahmad fauzan, m.Pd., M.Sc and Mr. Drs. Hendra Syarifuddin, M.Si., Ph.D. as a advisor and post-graduate lecturer of Universitas Negeri Padang who has provided guidance and direction with sincere heart and patient in the completion of this article. This article was prepared based on a thesis written by Nurkumala Sari entitled "The Development of Learning Instrument on Guided Discoverybased Learning to Improve Students Mathematical Problem-solving Ability in Semester 2 Grade VIII SMP/MTs"

\section{References}

[1] Depdiknas. 2006. Permendiknas No. 22 tentang Standar Isi untuk Satuan Pendidikan Dasar dan Menengah. Jakarta: Depertemen Pendidikan Nasional.

[2] Ruseefendi, E. T. 1993. Pendidikan Matematika 3. Jakarta: Universitas Terbuka.

[3] Plomp, T and Nieveen, N. 2007.An Introduction toEducational Design Research. Enschede: Netherland Institute for Curriculum Development (SLO). 